\title{
OD MAAPÄEV DO RIIGIKOGU. PROCES TWORZENIA ESTOŃSKIEGO PARLAMENTARYZMU PO I WOJNIE ŚWIATOWEJ
}

\author{
FROM MAAPÄEV TO RIIGIKOGU. THE PROCESS OF FORMING ESTONIAN \\ PARLIAMENTARISM AFTER THE FIRST WORLD WAR
}

The actions of the Russian Provisional Government which came to power in February 1917 were in general supported by the Estonian nationalists. The Committee of the Estonian Knighthood stated in the name of the Estonian Baltic nobles and local governments that it supported the actions of the Provisional Government and called all classes to follow its instructions and orders. After the February revolution the Estonian national movement urged the reform of local self-governments and the uniting of the Governorate of Livonia counties inhabited by Estonians with the Governorate of Estonia. This was achieved. In October of 1917, after the Bolsheviks came to power in Petrograd, representatives of Estonian bourgeois circles raised the call for independence. This resulted primarily from the Bolsheviks' approach to property rights. Estonian Bolsheviks, however, believed that the future of the Governorate of Estonia could only be bound to Soviet Russia. For the Baltic Germans, the 1917 Russian revolutions and the resultant seeking of autonomy by the Estonians and Latvians was a threat to their elitist position and the class system. Therefore, they welcomed the German occupation and strove for Estonia's union with Germany or for the creation of a dukedom allied with Germany. The plan for a dukedom did not materialize. The German occupation of Estonia brought with it, on the one hand, the destruction of Bolshevik power, and on the other hand, the genesis of Estonian national unity and the feeling of belonging together. The Constituent Assembly, elected in February-March of 1919, established the bases for Estonia's governing system: the constitution and the agrarian law. The adoption of the Agrarian Reform Law and the solving of land issues so that it met the expectations of the majority of the people created a situation where thousands of soldiers felt that they were fighting for their own land. This contributed markedly to winning the War for Independence. Based on the agrarian law and other supplemental decisions, during the period 1919-1939, 48,288 smallholdings were established. The constitution and the agrarian law finally ended the power of the Baltic nobility over the fate of the Estonian people. The text of the constitution adopted by the Constituent Assembly in 1920 remained largely in effect in the subsequent constitution but what changed was the structure of the government. In 1932 and 1933, the electorate was asked to vote on a total of three constitution projects. The last of these received the majority of votes in the October 1933 voting and went into effect as the constitution on 24 February 1934. This second constitution provided for the creation of the office of a president with far-reaching powers. The presidential election could not be held, as on 12 March 1934 a coup took place which insured that the Head of State, Konstantin Päts, retained power. In February 1936 the Head of State decided to ask the people to vote on whether a new constitution should be framed and whether a bicameral National Assembly (Rahvuskogu) should be elected. A general election was held and in early summer of 1937 the National Assembly prepared the text of the constitution, using as model also the constitution of Poland. This became law after a vote in the National Assembly and after the Head of State's decree and went into effect on 1 January 1938.

Słowa kluczowe: parlamentaryzm estoński, I wojna światowa, ukonstytuowanie parlamentu, Maapäev, Riigikogu, Asutav Kogu

Key words: Estonian parliamentarism, First World War, establishing the Estonian parliament, Maapäev, Riigikogu, Asutav Kogu

* Prof. Magnus Ilmjärv, Ajaloo Instituut, magnus.ilmjarv@tlu.ee, https://orcid.org/0000-0003-1405-4985 


\section{UWAGI WSTĘPNE}

I iteraturę na temat tworzenia się estońskiego parlamentaryzmu można umow-

nie podzielić na cztery grupy: literaturę opublikowaną w I Republice Estońskiej, literaturę opublikowaną w Związku Radzieckim, literaturę opublikowaną w krajach zachodnich przez uchodźców z krajów nadbałtyckich oraz literaturę opublikowaną po odzyskaniu niepodległości przez kraje nadbałtyckie. Mimo to temat nie został jeszcze wyczerpany. Wydarzenia z lat 1917-1920 w krajach nadbałtyckich i uzyskanie niepodległości przez te państwa z pewnością wymagają dalszych, szeroko zakrojonych studiów nad archiwami państw nadbałtyckich, Rosji i krajów zachodnich. W artykule przeanalizowano, jak dwie rewolucje 1917 r. w Rosji wpłynęły na gubernie Imperium Rosyjskiego: estońską i liwońską (inflancką). Następnie omówiono ewolucję myśli niepodległościowej w Estonii: od domagania się autonomii do ogłoszenia niepodległego państwa, zrodzenia się pomysłu wyborów do Zgromadzenia Założycielskiego (Asutav Kogu), przez wybory do Zgromadzenia Założycielskiego i akty prawne uchwalone przez to Zgromadzenie.

„W południe otrzymano wiadomość o abdykacji cesarza Mikołaja II. Bajka stała się rzeczywistością. Marzenie, o którym jeszcze parę dni wcześniej nawet nam się nie śniło, stało się teraz faktem dokonanym" — - tak opisywał swoje uczucia i nastroje z lutego 1917 r. Hans Kruus, bezpośredni świadek wydarzeń, jeden z najbardziej znanych estońskich historyków.

Władza w guberniach estońskiej i liwońskiej w pierwszych dziesięcioleciach XX w. znajdowała się w rękach arystokracji wywodzącej się z bałtyckich Niemców. W guberniach estońskiej i liwońskiej rządzili gubernatorzy mianowani przez władze centralne razem z Sejmikiem Krajowym (Maapäev, niem. Landtag) składającym się z Niemców bałtyckich. Sejmik Krajowy, którego członkami byli przedstawiciele niemieckiej szlachty, jego instytucje, konwenty, komitety, zgromadzenia okręgowe, radcy ziemscy i ich kolegia oraz kierownictwo rycerstwa, czyli szlachty niemieckiej, zapewniały zachowanie porządku stanowego. Prawo głosu w Sejmiku mieli tylko posiadacze ziemscy wywodzący się ze szlachty i wpisani do stosownej metryki szlacheckiej, czyli do księgi rodów. W Sejmiku mogli również uczestniczyć — z prawem do wypowiedzi — posiadacze ziemscy należący do stanu obywatelskiego oraz przedstawiciele miasta Tallinna. Członkami wybieranego przez SK Kolegium Rady Ziemskiej (Maanõukogu) mogli zostać tylko posiadacze ziemscy stanu szlacheckiego, przy czym urząd obejmowany w wyniku wyborów był dożywotni. W wyborach samorządów miejskich mogli brać udział tylko właściciele domów i zamożni kupcy, co sprawiało, że samorządy miejskie były zdominowane przez posiadaczy ziemskich wywodzących się z bałtyckich Niemców.

Ziemię w guberniach estońskiej i liwońskiej na podstawie bałtyckiej ustawy specjalnej (Liv-, Est- und Curländisches Privatrecht) dzielono na następujące kategorie: majątki i grunty państwowe, majątki rycerskie, majątki należące do rycerstwa, do miast,

${ }^{1}$ H. Kruus, Peetrilinnas ajaloo suurpäevil. Veebruar märts 1917, Tartu 1917. 
do stowarzyszeń, do stanów oraz do instytucji dobroczynnych, grunty kościelne, grunty wiejskie (Landstellen) i działki ziemi (Gutsabteilungen). Około 58\% ziemi należało do rycerstwa, duchowieństwa i urzędników carskiej Rosji. Według danych spisu ludności z 1897 r. 13\% mieszkańców prawie milionowej Estonii mieszkało w miastach, a 87\% na wsi². Prawie połowa mieszkańców wsi guberni estońskiej i liwońskiej była wykorzystywana przez właścicieli wielkich majątków, którzy nie byli Estończykami ani Łotyszami i nie byli związani z lokalną społecznością. Cała logika władzy w tych guberniach sprowadzała się do prostej zasady — nie dopuścić do udziału przedstawicieli rdzennego ludu tej ziemi w organach władzy i zachować w kraju na wpół feudalny porządek.

Na początku 1917 r. większa część terytorium dzisiejszej Litwy i połowa terytorium dzisiejszej Łotwy była okupowana przez wojska niemieckie. Wiadomości o wybuchu rewolucji i obaleniu władzy cara dotarły do guberni estońskiej i liwońskiej z opóźnieniem. Obie gubernie natychmiast zostały wciągnięte $\mathrm{w}$ wir tych wydarzeń. Już w pierwszych dniach marca władze obu guberni przestały istnieć. 3 marca 1917 r. rosyjski Rząd Tymczasowy ogłosił deklarację, w której oznajmił, że więźniowie polityczni zostaną zwolnieni, a w państwie będzie obowiązywać wolność słowa, zgromadzeń i druku. Jednym z pierwszych kroków Rządu Tymczasowego w guberniach była likwidacja autonomii nadanej bałtyckim Niemcom po $1710 \mathrm{r}$. Prawdopodobnie nowa władza w Petersburgu nie miała złudzeń co do tego, że bałtyccy Niemcy sympatyzują z Rzeszą Niemiecką. 5 marca komisarzem guberni estońskiej mianowano Iwana Poskę, dotychczasowego burmistrza Tallinna, natomiast komisarzem guberni liwońskiej Andreisa Krastkalnsa, dotychczasowego burmistrza Rygi.

Pomysł połączenia wszystkich okręgów guberni liwońskiej, zamieszkałych przez Estończyków, z gubernią estońską pojawił się już w końcu XIX w. W przemówieniu z 22 maja 1916 r. Jüri Vilms, członek Stronnictwa Pracy Estonii, żądał autonomii kulturowej dla Estończyków³. Podobne nastroje panowały również w Vidzeme, w południowych częściach guberni liwońskiej zamieszkałych przez Łotyszy. 11-13 marca w należącym do guberni liwońskiej mieście Tartu odbyło się zgromadzenie, w którym uczestniczyli przedstawiciele towarzystw estońskich z guberni estońskiej i liwońskiej. Głównym tematem poruszanym na tym zebraniu była kwestia autonomii i lokalnych samorządów. Na podstawie decyzji zgromadzenia 17 marca przedstawiono Rządowi Tymczasowemu odpowiednie memorandum. Początkowo Rząd Tymczasowy odmówił autonomii i włączenia terenów zamieszkałych przez Estończyków do jednej guberni, $\mathrm{w}$ wyniku czego estońscy narodowcy podjęli decyzję w sprawie przedstawienia swoich politycznych żądań. W celu wywarcia presji na Rząd Tymczasowy postanowiono zorganizować demonstrację. 23 marca w estońskiej gazecie w Petersburgu „Pealinna Teataja" opublikowano wezwanie Estońskiego Związku Republikanów do estońskich żołnierzy garnizonu w Petersburgu, robotników i uczącej się młodzieży, aby 26 marca stawili się oni pod Pałacem Taurydzkim w celu przekazania Rządowi Tymczasowemu

2 Vide Первая всеобщая перепись населения Российскои империи 1897 года. Эстляндская, Лифляндская губерния, ред. Н.А. Тройницкий, <https://www.twirpx.com>, dostęp 1 VI 2018.

${ }^{3}$ R. Berendsen, Eestimaa talurahva vabastamise 100 aasta juubel 23. mail 1916, Tallinn 1916, s. 43. 
politycznych żądań ${ }^{4}$ Wezwanie, zatytułowane „Niech żyje Republika Rosyjska i autonomiczna Estonia”, powtórzono w numerze z 25 i 26 marca.

W gazecie „Pealinna Teataja” z 28 marca tak opisano demonstracje Estończyków zorganizowane 26 marca w celu wsparcia estońskiej autonomii: „Około 40 tys. głów razem, ponad 100 flag i 30 orkiestr dętych”. 29 marca ta sama gazeta następująco skorygowała podaną wcześniej liczbę uczestników demonstracji z 26 marca: „Jednym słowem 26 marca po ulicach Petersburga przeszła 10-, 12-tysięczna armia estońska”. Informacje opublikowane w „Pealinna Teataja” z 28 marca, jakoby w demonstracji uczestniczyło 40 tys. Estończyków, są powtarzane do dzisiaj ${ }^{5}$. Należy zaznaczyć, że w materiałach opublikowanych w latach dwudziestych i trzydziestych XX w. liczbę uczestników opisywanej demonstracji szacowano na mniej, czyli na 10, 15 tysięcy $^{6}$. Zgodnie ze spisem ludności z 1897 r. w Sankt Petersburgu mieszkało 12238 Estończyków, a w Leningradzie — zgodnie ze spisem ludności z 1926 r. - 15 847. Liczbę Estończyków mieszkających w guberni sankt-petersburskiej szacowano na 64 tys., w tym około 10 tys. Estończyków mieszkających w mieście Narwa. Nie ma możliwości dokładnego określenia liczby uczestników demonstracji, ponieważ część Estończyków mieszkała w Petersburgu bez rejestrowania się. Jest rzeczywiście możliwe, że 26 marca przed Pałacem Taurydzkim zebrało się około 40 tys. osób, w tym około 10 tys. Estończyków, których głównym żądaniem była autonomia guberni estońskiej i włączenie terenów guberni liwońskiej zamieszkałych przez Estończyków do guberni estońskiej.

Dnia 30 marca 1917 r. Rząd Tymczasowy wydał postanowienie o administracyjnym zarządzaniu i organizacji czasowego samorządu w guberni estońskiej, po czym 25 czerwca tego samego roku wydano postanowienie o wprowadzeniu go życie. Tymi dwoma aktami prawnymi administracyjnie przyłączono okręgi zamieszkałe przez Estończyków z guberni liwońskiej do guberni estońskiej. W ten sposób utworzono jednostkę administracyjną o stałych granicach, obejmującą tereny zamieszkałe przez Estończyków.

Po rewolucji lutowej dowództwo oddziałów estońskich wysłało do Rządu Tymczasowego telegram, w którym zadeklarowało swoją wobec niego lojalność. Wtedy jednak bałtyccy Niemcy uznali dekret rosyjskiego Rządu Tymczasowego z 30 marca za złamanie warunków kapitulacji z dnia 19 września 1710 r. i umowy pokojowej z Nystad, w którym potwierdzono prawa niemieckiej szlachty bałtyckiej w Estonii i Inflantach do utrzymania swojego systemu finansowego, istniejącej granicy celnej, samorządu, religii luterańskiej i języka niemieckiego.

${ }^{4}$ Vide „Pealinna Teataj”, 23 III 1917.

5 Vide A. Tamm, Eesti meeleavaldus Peterburis 26. märtsil 1917, „Kaitse Kodu” 1928, nr 3, s. 134; E. Laaman, Eesti isesievuse sünd, Tartu 1936, s. 92, 94.

6 „Päevaleht”, 24 II 1938; O. Kurvits, Eesti rahvusväeosad 1917-1918. Eesti rahvusväeosade album II, Tallinn 1937, s. 14.

7 Архив новейшей истории России, t. VII, Журналы заседаний Временного правительства: март-октябрь 1917 г., март-апрель 1917 г.; Российская политическая энииклопедия, Москва 2001, s. 449. Vide także A. Piip, Tormine aasta. Ülevaade Eesti välispoliitika esiajast 1917.-1918. aastal dokumentides ja mälestusis, Tartu 1934, s. 8. 
Po rewolucji lutowej w Rosji zwolennicy ruchów narodowościowych w Estonii i na Łotwie wspierali — podobnie jak inteligencja — Rząd Tymczasowy, który doszedł do władzy. Na przykład Otto Strandman, przyszły naczelnik państwa w Estonii i radykalny narodowiec, 10 kwietnia 1917 r. deklarował w odpowiedzi na przemówienie Aleksandra Kiereńskiego w Tallinnie w teatrze Estonia: „W imieniu zebranych przedstawicieli ludu Estonii witam pana Aleksandrze Fiodorowiczu [...]. Zobowiązano mnie do zwrócenia się do pana z prośbą o powiadomienie Rządu Tymczasowego, że naród estoński powierza swój los Zgromadzeniu Ustawodawczemu Rosji [...]. Aspirujemy do porządku autonomicznego, ale nie słychać u nas głosów za oderwaniem się od Rosji”. Według prasowych relacji mieszkańcy Estonii, którzy przyszli wysłuchać przemówienia, zareagowali na to burzliwymi oklaskami. Kiereński w odpowiedzi na przemowę Strandmana stwierdził, że obywatele Estończycy muszą wiedzieć, że wolna Rosja wybierze Zgromadzenie Ustawodawcze po to, aby proklamowało ono demokratyczną republikę, że Rosja chciałaby, aby Estończycy pozostali z Rosją, że naród estoński nigdy nie był przeciwko narodowi rosyjskiemu, ale przeciwstawiał się wyłącznie tyranii ${ }^{8}$. 12 czerwca 1917 r. Jüri Vilms pisał: „,Tłumaczyliśmy, że my żądamy od rosyjskiego Zgromadzenia Ustawodawczego zrealizowania naszej narodowo-politycznej idei. Dotychczas naszym ideałem był porządek federacyjny w Rosji, w którym Estonia byłaby jednym z podmiotów federacji. My nie żądamy niepodległości Estonii, ponieważ naszym zdaniem w kontekście losów naszego narodu i naszej ziemi nie ma potrzeby żądać niepodległości. [...] Nigdzie w społeczności estońskiej nie żądano niepodległości ani nie było o tym w ogóle mowy" . Nie była to do końca prawda, zdarzali się pojedynczy marzyciele również w latach wcześniejszych.

\section{WLADZA BOLSZEWIKÓW W ESTONII OD LISTOPADA 1917 R. DO LUTEGO 1918 R.}

Dnia 24 i 25 października 1917 r. w Petersburgu bolszewicy dokonali rewolucji. 27 października w gazetach guberni estońskiej opublikowano specjalny telegram nadesłany z Petersburga. Chodziło o wiadomość o tym, że wszyscy członkowie rosyjskiego Rządu Tymczasowego zostali uwięzieni w Twierdzy Pietropawłowskiej i że tylko Aleksandrowi Kiereńskiemu udało się uciec ${ }^{10}$. Wówczas Komitet Wojskowo-Rewolucyjny Estonii mianował swoich komisarzy. Tego samego dnia komisarz guberni estońskiej I. Iwanowicz Poska własnoręcznie podpisał akt, w którym wskazywał, że w związku z dokonanym zamachem stanu przekazuje on kierowanie gubernią pełnomocnikowi Rady Komitetu Wykonawczego Komitetu Wojskowo-Rewolucyjnego Guberni Estońskiej Viktorowi Kingisseppowi ${ }^{11}$. Kingissepp natychmiast wystąpił do lokalnych władz samorządowych z propozycją, aby wszyscy komisarze złożyli swoje

\footnotetext{
${ }^{8}$ Kohtuminister Kerenski kõne Estonia (przemówienie ministra sprawiedliwości Kerenskiego w Estonii), ,Päevaleht”, 11 IV 1917.

9 J. Vilms, Eesti rahva pü̈ded ja Vene punane tagurlus, „Päevaleht”, 29 VI 1917.

10 „Ревельская Мысль”, 27 X 1917.

11 Акт от 27 X 1917. ERA 1290-1-5, s. 2.
} 
pełnomocnictwa. Jednocześnie urzędnicy otrzymali polecenie, aby kontynuować pracę ${ }^{12}$. Do 17 i 18 grudnia 1917 r. w okręgach odbywały się kongresy rad, na których przedstawiciele gmin wybierali rady okręgów. Obalenie caratu pociągnęło za sobą wzrost przestępczości, która objawiała się m.in. samowolnymi zajęciami i pogromami w majątkach. Rewolucja październikowa w Rosji była dla obywatelskich kręgów Estonii zjawiskiem nieprzyjemnym. Uważano, że Rosja nie jest jeszcze gotowa do budowy socjalistycznego społeczeństwa. Nacjonalizacja ziemi i konfiskowanie majątków przez bolszewików budziły ostrą krytykę. Twierdzono, że bolszewicy nie poradzą sobie z gospodarowaniem w majątkach. Wróżono, że armia niemiecka, która wkrótce miała nadciągnąć, ukarze osoby, które przejęły majątki. Prawdą jest jednak, że popierano hasło bolszewików dotyczące prawa do samostanowienia narodów.

Przełom w kwestii stosunku do autonomii Estonii i jej niepodległości nastąpił w związku z rewolucją październikową w Rosji. W 1935 r. Ants Piip pisał, że ponieważ Rosja sowiecka - powstała w wyniku rewolucji i nieuznająca carskiego ustawodawstwa - była państwem, które swojej władzy nie otrzymało od obywatelskiego rządu Rosji legalnie, to dla Estończyków nie była ona już władzą prawomocną ${ }^{13}$.

W wyborach do rosyjskiego Zgromadzenia Ustawodawczego, które odbyły się w guberni estońskiej w dniach od 12 do 14 listopada 1917 r., bolszewicy otrzymali 39,9\% głosów, co przekładało się na tyle samo miejsc, ile inne partie uzyskały łącznie. W Tallinnie na bolszewików głosowało 47,6\% wyborców, więc poczuli się oni w Estonii pewnie. Niemniej było również wiele osób, które miały nadzieję, że rosyjskie Zgromadzenie Ustawodawcze opracuje konstytucję, która będzie podstawą demokratycznego ustroju państwowego w Rosji, przeprowadzona reforma rolna, wprowadzona kontrola robotników nad przemysłem i handlem i że wojna zostanie zakończona. Mówiono również o tym, że rosyjskie Zgromadzenie Ustawodawcze powinno szanować prawo narodów do samostanowienia ${ }^{14}$.

Komitet Wykonawczy Rady Przedstawicieli Robotników, Żołnierzy, Bezrolnych i Małorolnych Estonii (składający się z bolszewików) widząc, że nadchodzi przytłaczające zwycięstwo 12 listopada, podjął decyzję — powołując się na deklarację praw narodów Rosji - o zwołaniu Zgromadzenia Założycielskiego. Bolszewicy oskarżali kręgi obywatelskie o to, że nie chciały one uznać legalności sowieckiej władzy i agitowały przeciwko sowieckiemu rządowi ${ }^{15}$. Ustalono termin wyborów do Zgromadzenia Założycielskiego i termin jego zwołania, odpowiednio na 21 i 22 stycznia oraz 15 lutego 1918 r. W tej samej decyzji informowano o rozwiązaniu Tymczasowej Rady Ziemskiej Guberni Estońskiej, co uzasadniano tym, że nie została ona wybrana w sposób demokratyczny. Odnośnie do Rządu Krajowego guberni podjęto natomiast decyzję, że zachowuje on swe pełnomocnictwa i ma nadal pracować ${ }^{16}$. W celu przeprowadzenia wyborów

\footnotetext{
12 Приказ от 27 X 1917. ERA 1290-1-5, s. 4.

13 J. Uluots, Grundzüge der Agrargeschichte Estlands, University of Minnesota 1935, s. 123.

${ }^{14}$ Vide H. Pöögelmann, Asutav Kogu ja rahvavalitsus (rękopis). ERA 3742-1-53, s. 1-24.

15 Vide „Tööline”, 17 (30) XI 1917.

16 Vide „Eestimaa Kubermangu Teataja”, 13 XI 1917.
} 
do Zgromadzenia Założycielskiego stworzono Centralną Komisję Wyborczą estońskiego Zgromadzenia Założycielskiego, której przewodniczącym został bolszewik Voldemar Vöölmann. Wydano także postanowienie dotyczące wyborów, w którym określono wielkość Zgromadzenia Założycielskiego. Miało ono liczyć 100 członków, którzy mieli być wybierani przez mieszkańców obu płci w powszechnym, bezpośrednim i tajnym głosowaniu, na podstawie proporcjonalnej ordynacji wyborczej ${ }^{17}$. Niezależnie od tego, że bolszewicy początkowo informowali, że urzędnicy Rządu Krajowego mają pozostać na swoich stanowiskach i wykonywać swoje obowiązki, to tej obietnicy nie dotrzymano. 19 listopada poinformowano, że pełnomocnictwa Rządu Krajowego wygasły.

O stworzeniu organu władzy, który rozwiązał Tymczasową Radę Ziemską, czyli Komitetu Wykonawczego Rady Przedstawicieli Robotników, Żołnierzy, Bezrolnych i Małorolnych Estonii zadecydowano na Kongresie Rad Estonii, który odbył się w Tallinnie w dniach 12-14 października. Na kongresie podjęto decyzję, że lokalni mieszkańcy będę wybierali swoich przedstawicieli (wskazywanych przez samorządy) do Komitetu Wykonawczego. W skład Komitetu Wykonawczego weszli głównie bolszewicy. 27 października na przewodniczącego Komitetu Wykonawczego wybrano członka Tymczasowej Rady Ziemskiej Jaana Anvelta. 15 listopada przewodniczący Rady Ziemskiej Guberni Estońskiej O. Strandmann odczytał w Radzie Ziemskiej odręcznie napisane pismo Komitetu Centralnego Rady Robotników, Żołnierzy i Chłopów Estonii, które zawierało wspomnianą decyzję ${ }^{18}$. Podpisał ją również członek tej samej Tymczasowej Rady Ziemskiej J. Anvelt. Tym samym chodziło wyłącznie o rozwiązanie Tymczasowej Rady Ziemskiej i wybory do Zgromadzenia Założycielskiego mającego wypracować plan utworzenia przyszłej bolszewickiej Estonii, który następnie chciano poddać pod referendum.

W trakcie działalności Rządu Tymczasowego organem doradczym komisarza guberni estońskiej była Tymczasowa Rada Ziemska licząca 66 członków. Wyłoniono ją nie w wyborach powszechnych, lecz podczas zgromadzeń wyborczych w okręgach i w miastach, zgodnie z zasadą: jeden poseł na każde 200 tys. mieszkańców ${ }^{19}$. W Tymczasowej Radzie Ziemskiej zasiadali także przedstawiciele bałtyckich Niemców i bolszewików; spośród Niemców bałtyckich np. Max Bock, przedstawiciel Niemców z miasta, a spośród znanych estońskich bolszewików byli to: Artur Vallner (przewodniczący Tymczasowej Rady Ziemskiej od lipca do października 1917 r.), J. Anvelt, Hans Pöögelmann, A. Leetsmann i Jaan Sihver. Frakcja bolszewików już we wrześniu 1917 r. zażądała, aby Tymczasową Radę Ziemską wybrać w powszechnych, tajnych wyborach zgodnie z proporcjonalną ordynacją wyborczą. Przed rewolucją październikową

17 Vide Eesti Töörahva ja sõjaväelaste Nõukogu Täidesaatva Komitee otsused ja määrused Eesti Asutava Kogu asjus (decyzje i regulaminy Estońskiego Komitetu Wykonawczego Pracowników i Sił Zbrojnych w sprawie Zgromadzenia Estońskiego), przedruk z „Eestimaa Kubermangu Teataja” i „Eesti Teataja". ERA R-1937-1-34.

18 Teadanne nr 1. Eestimaa elanikele, 27 XI 1917 (ogłoszenie nr 1. do mieszkańców Estonii). ERA R.1937-1-35, s. 1.

19 Vide A.T. Kliimann, Eesti iseseisvuse areng, Tartu 1935, s. 9. 
na posiedzeniach Rady Ziemskiej także wyrażano opinie, że gubernia estońska musi pozostać autonomiczną częścią demokratycznej i federacyjnej Rosji.

Natomiast w sprawie Zgromadzenia Założycielskiego w Tymczasowej Radzie Ziemskiej formułowano opinie rozbieżne. Bolszewicy popierali Zgromadzenie, a reprezentanci prawicy uważali, że skoro instytucje państwowe Rosji nie zostały wybrane w sposób demokratyczny, to z tego punktu widzenia Rada Ziemska jest wystarczająco demokratyczna. Na posiedzeniu Rady Ziemskiej z 26 września 1917 r. postanowiono, że zostanie wybrana dziewięcioosobowa komisja, która opracuje wstępny projekt ustawy o przyszłych samorządach i rządach w Estonii, oraz że o poddaniu projektu ustawy pod referendum zdecyduje Zgromadzenie Założycielskie. Podstawą projektu ustawy miała być zasada, że Estonia pozostanie autonomiczną częścią demokratycznej i federacyjnej Rosji. Taka komisja została powołana, a w jej skład wszedł także członek Tymczasowej Rady Ziemskiej bolszewik Anvelt ${ }^{20}$. Na posiedzeniu Rady Ziemskiej z 2 października omawiano właśnie kwestię wyborów do nowej Rady Ziemskiej, którą nazwano Sejmikiem Krajowym. Dyskusje, które toczyły się na ten temat, dotyczyły przede wszystkim liczby członków Sejmiku Krajowego, tego czy powinien on liczyć 100, czy 120 posłów. Ostatecznie postanowiono, że w jego skład będzie wchodziło 100 posłów ${ }^{21}$.

W odpowiedzi na pismo bolszewików Tymczasowa Rada Ziemska 15 listopada wydała rezolucję, w której poinformowano, że nie jest znany zakres uprawnień Komitetu, który powiadomił o rozwiązaniu Tymczasowej Rady Ziemskiej, że obywatele Estonii nie uznali Komitetu za nadrzędną władzę w kraju i w związku z tym jego decyzja nie zostanie poddana pod dyskusję. Odpowiedź na decyzję bolszewików jednak wystosowano - Tymczasowa Rada Ziemska wydała odezwę do obywateli Estonii, w której deklarowała, że w celu uniknięcia zamętu należy „stworzyć własny narodowy rząd”, że jedynym nośnikiem narodowej władzy państwowej jest Tymczasowa Rada Ziemska i Rząd Krajowy (Maavalitsus), które muszą wprowadzić stabilny porządek w państwie ${ }^{22}$. Przyjęto również deklarację, w której oznajmiono, że Rada Ziemska — zgodnie z zasadą samostanowienia narodów - w celu wprowadzenia porządku w państwie postanowiła zwołać Zgromadzenie Założycielskie. W deklaracji oznajmiono też, że Zgromadzenie Założycielskie zostanie wybrane na podstawie ordynacji wyborczej przygotowanej dla Zgromadzenia Ustawodawczego Rosji, do którego zostaną wprowadzone pewne poprawki. Jednocześnie ogłoszono gotowość do negocjacji z utworzonym przez bolszewików Centralnym Komitetem Rady Robotników, Żołnierzy i Chłopów Estonii w celu rozwiązania rozbieżności w kwestiach nadchodzących wyborów ${ }^{23}$. Rada Ziemska

20 Vide Ajutise Maanõukogu koosoleku protokoll, 26 IX 1917 (protokół posiedzenia Tymczasowej Rady Ziemskiej). ERA 78-1-91, s. 4.

${ }^{21}$ Maanõukogu istungi protokoll, 2 X 1917 (protokół posiedzenia Rady Ziemskiej); valimisseaduse alusmõtted, 2 X 1917 (podstawy ordynacji wyborczej). ERA 78-1-91, s. 4

22 Vide Ajutise Maanõukogu koosoleku protokoll, 15 XI 1917 (protokół zebrania Tymczasowej Rady Ziemskiej). ERA 78-1-97, s. 2, 9.

23 Vide Ajutise Maanõukogu, 15 XI 1917 toimunud koosoleku protokolli lisa nr 1 (załącznik nr 1 do protokołu zebrania Tymczasowej Rady Ziemskiej). ERA 78-1-110, s. 1-2. 
zwróciła się również z wezwaniem do estońskich żołnierzy odbywających służbę w rosyjskiej armii, aby żądali oni odesłania ich do ojczyzny i to wraz z bronią w celu zapewnienia w Estonii porządku i praworządności $\mathrm{i}^{24}$.

Decyzję Tymczasowej Rady Ziemskiej uważano za swoistą deklarację niepodległości, akt ogłoszenia niepodległości państwa, za oderwanie się guberni estońskiej od Rosji, lecz tak naprawdę zadeklarowano w niej jedynie, że ponieważ w Rosji panuje bałagan i chaos, to Rada Ziemska staje się najwyższą władzą w Estonii.

Dnia 5 stycznia 1918 r. odbyło się w Petersburgu pierwsze i jedyne posiedzenie rosyjskiego Zgromadzenia Ustawodawczego. Wybory do tego ciała odbywały się w guberni estońskiej w dniach 12-14 listopada 1917 r., a bolszewicy odnieśli w nich zdecydowane zwycięstwo ${ }^{25}$. Z członków Tymczasowej Rady Ziemskiej Guberni Estońskiej do Zgromadzenia Ustawodawczego Rosji wybrano J. Anvelta, H. Pöögelmana, J. Vilmsa, Juliusa Seljamaa i Jaana Tõnissona. Oprócz nich do Zgromadzenia Ustawodawczego wybrano jeszcze trzy osoby z guberni estońskiej: I. Poskę sprawującego wcześniej urząd komisarza guberni, bolszewików: Rudolfa Vakmana i Iwana Rabtšinskiego. Wypowiadający się w Zgromadzeniu Ustawodawczym J. Seljamaa nie mówił nic o oderwaniu się od państwa rosyjskiego. Według niego Estończycy chcieliby uzyskać niezależność i decydować o przyszłym porządku państwa. Seljamaa sam w swoich później spisanych wspomnieniach przyznał, że nad deklaracją Estonii w kwestii niepodległości w Zgromadzeniu Ustawodawczym Rosji dyskutowano już wcześniej, lecz podjęto decyzję o konieczności skoordynowania działań z przedstawicielami innych narodów Rosji, wybranymi do Zgromadzenia, i o czekaniu na odpowiednie działania estońskiego Zgromadzenia Założycielskiego w tej kwestii ${ }^{26}$. Eduard Laaman, jeden z ideologów estońskiej państwowości, także przyznał w swojej książce opublikowanej w 1920 r., Oderwanie się Estonii od państwa rosyjskiego, że decyzja Tymczasowej Rady Ziemskiej z 15 listopada sama w sobie nie była żadnym zamachem stanu, lecz była jedynie pomyślana jako próba stworzenia konfederacji, w której każde z państw członkowskich byłoby suwerenne ${ }^{27}$. Natomiast rezolucja Tymczasowej Rady Ziemskiej z 15 listopada była wezwaniem do niewykonywania aktów prawnych wydawanych przez bolszewików. Niemniej rzeczywista i coraz większa władza skupiała się w rękach bolszewików, którzy nie przywiązywali żadnej wagi do rezolucji Rady. W zaistniałej sytuacji Tymczasowej Radzie Ziemskiej brakowało możliwości urzeczywistnienia zadeklarowanych planów. Choć powtarzano, że decyzje bolszewików nie podlegają wykonaniu, to istniała zgoda na ich wykonywanie tam, gdzie interesy Rady i interesy bolszewików były zbieżne. Zgodzono się na przykład na zorganizowanie wyborów do Zgromadzenia Założycielskiego. Z Centralną

${ }^{24}$ Vide Ajutise Maanõukogu, 15 XI 1917 toimunud koosoleku protokolli lisa nr 2 (załącznik nr 2 do protokołu zebrania Tymczasowej Rady Ziemskiej). ERA 78-1-110, s. 8. J. Kukk, Kaks , ülewõtmist”. Iseseiswue tuleku Päiwilt. Mälestused, Tartu 1923.

25 „Утро Правды”, 30 XI (13 XII) 1917.

26 J. Seljamaa, Eesti esimesed diplomaatilised suhted suurriikidega. ERA 3828-1-2, s. 2-3.

27 E. Laaman, Eesti lahkumine Vene riigist 1917-1920, Tallinn 1920, s. 33. 
Komisją Wyborczą aktywnie współpracowało kilku prominentnych polityków, jak Jüri Jaakson i Mihkel Martna ${ }^{28}$. Nie protestowano również przeciwko przyłączeniu miasta Narwa do guberni estońskiej. Bolszewik Ants Daumann, który po rewolucji lutowej został burmistrzem Narwy, przeprowadził referendum, a następnie wystosował prośbę do Rosyjskiej Rady Komisarzy Ludowych o administracyjne przekazanie miasta guberni estońskiej. 16 listopada 1917 r. Lenin podpisał decyzję, na mocy której Narwę i Iwangorod wydzielono $\mathrm{z}$ okręgu jamburskiego i administracyjnie zaliczono do guberni estońskiej.

Na scenie politycznej pojawiła się trzecia siła. Po dojściu bolszewików do władzy Niemcy bałtyccy nie mieli już powodów do wiązania się z Rosją. Przedstawiciele rycerstwa, czyli arystokracji, w reakcji na decyzję Sejmiku Krajowego z 15 listopada wystosowało prośbę do Niemiec, aby wzięły Estonię pod swoją opiekę. 30 listopada (13 grudnia) 1917 r. Komitet Rycerstwa Estonii ogłosił niezależność guberni estońskiej od Rosji i oznajmił, że los Estonii składa w ręce cesarza Niemiec. Jednocześnie skierowano do cesarza Niemiec prośbę, aby okupował gubernię estońską. 17 września decyzję o podobnej treści podjął także Landtag Rycerstwa Liwonii ${ }^{29}$. Przy czym rycerstwo opierało się na wydanej przez bolszewików deklaracji praw narodów Rosji. 28 stycznia 1918 r. przedstawiciele rycerstwa Estonii i Liwonii przekazali przedstawicielowi sowieckiej Rosji w Sztokholmie Wacławowi Worowskiemu deklarację o odłączeniu Estonii i Liwonii od Rosji. Bałtyccy Niemcy zaczęli także agitować Estończyków i Łotyszy, aby zaakceptowali oni władzę cesarza Niemiec. W przypadku Estonii godne uwagi było pismo Paula Siegwarta von Kügelgen, bałtyckiego Niemca, byłego redaktora naczelnego „St. Petersburgische Zeitung”, w sprawie „umowy narodowej”, które ukazało się w styczniu 1918 r. w gazecie „Päevaleht”. Kügelgen wypowiedział wprost, że Estonia nie powinna liczyć na wsparcie państw zachodnich, że naród estoński nie jest w żaden sposób gotowy na niepodległość, a Estonia powinna natychmiast wybrać między Rosją a Niemcami. Kügelgen twierdził, że w wyniku rewolucji w Rosji w guberni zapanował chaos i nieporządek prowadzące naród do zatracenia, majątki były rozgrabiane, własność nie była szanowana, wybór mógł być zatem tylko jeden - Niemcy ${ }^{30}$.

Tym samym istniały dwa wezwania do uczestnictwa w wyborach do Zgromadzenia Założycielskiego: pierwsze wystosowane przez bolszewików i drugie przez Tymczasową Radę Ziemską Guberni Estońskiej. Powstała także trzecia siła, a wszyscy pragnęli władzy. Zarówno bolszewicy, jak i przedstawiciele kręgów prawicowych szli na wybory Zgromadzenia Założycielskiego ręka w rękę, jednocześnie krytykując się

${ }^{28}$ Vide Eesti Asutava Kogu Valimisasjade Keskkomisjon Jaaksonile 1 XII 1917 (Centralna Komisja Wyborcza do Estońskiego Zgromadzenia Założycielskiego do Jaaksona). ERA R. 1937-1-20, s. 9. Декреты Советской власти, t. 1, 25 октября 1917 г.-16 марта 1918 г., Москва 1957, s. 542. Vide K. Brüggemann, Baltisaksalsed ja Eesti iseseisvus 20. Sajandil, „Vikerkaar” 2018, nr 1-2, s. 161.

${ }^{29}$ E. Dellingshausen, Im Dienste der Heimat. Erinnerungen des Freihern Eduard von Dellingshausen, Stuttgart 1930, s. 318.

${ }^{30}$ P. Kügelegen, Eestimaa tulevik, „Päevaleht”, 10 (23) I 1918. 
nawzajem. Bałtyccy Niemcy w ogóle odmówili uczestnictwa w wyborach do Zgromadzenia Założycielskiego.

Dnia 22 grudnia upłynął termin zgłaszania kandydatów na posłów. W wyborach wystawiono dziewięć list. Swoje listy zgłosiły następujące Stronnictwa: Estońska Socjaldemokratyczna Partia Robotników — 92 kandydatów; Estoński Komitet Rosyjskiej Socjaldemokratycznej Partii Robotników, Komitet Centralny Bezrolnych i Małorolnych Estonii — 99 kandydatów; Estońskie Stronnictwo Pracy — 99 kandydatów; Estońska Partia Socjalistów Rewolucjonistów (prawicowi eserzy) — 50 kandydatów; Estońska Partia Socjalistów Rewolucjonistów (lewicowi eserzy) - 61 kandydatów; Związek Niepodległości Estonii - 18 kandydatów; Estoński Blok Demokratyczny - 100 kandydatów; Związek Chrześcijański - 12 kandydatów; Zjednoczona Demokratyczna Organizacja Rosyjskich Obywateli Tallinna - 15 kandydatów; Zjednoczone Demokratyczne Organizacje Rosyjskich Obywateli Miasta Tallinn - 15 kandydatów. Bałtyccy Niemcy nie przedstawili listy.

W trakcie wyborów do Zgromadzenia Założycielskiego zastanawiano się głównie nad dwiema sprawami: pierwsza dotyczyła wywłaszczonych gruntów właścicieli majątków, a druga wewnętrznego zarządzania w Estonii. Bolszewicy nie popierali parcelacji majątków, uważali to za działania nieefektywne i chcieli tworzyć w majątkach duże kolektywne gospodarstwa. Przedstawiciele partii obywatelskich opowiadali się za tym, żeby wywłaszczone majątki jednak rozparcelowywać na pojedyncze gospodarstwa, tak żeby ziemię mógł otrzymać każdy, czy to w formie renty dziedzicznej, czy też na podstawie prawa własności ${ }^{31}$.

Wybory do Zgromadzenia Założycielskiego rozpoczęły się 21 stycznia (4 lutego). Jednocześnie Centralna Komisja Wyborcza podjęła decyzję, aby w tych miejscach, gdzie nie zdążą z zorganizowaniem wyborów 21 i 22 stycznia, wybory mogły się odbyć w ciągu następnych dwóch tygodni, lecz nie później niż 5 lutego ${ }^{32}$. Jak wynika z informacji zamieszczanych $\mathrm{w}$ gazetach, problemem było przede wszystkim dostarczenie na miejsce materiałów wyborczych. Wybory odbywały się w czasie, kiedy część terytorium guberni estońskiej była okupowana przez Niemcy, a w Brześciu prowadzono rokowania pokojowe między Rosją a Niemcami i Austro-Węgrami. 29 września 1917 r. rozpoczęła się operacja wojsk niemieckich Albion, mająca na celu zdobycie strategicznie ważnego Archipelagu Moonsundzkiego (Ösel, Dagö i inne wyspy) ${ }^{33}$. Korzystanie $\mathrm{z}$ archipelagu Moonsund pozwalało flocie rosyjskiej przemieszczać się od Zatoki Ryskiej do wybrzeży Kurlandii, poruszać się po centralnej części Bałtyku i nie dopuszczać do wymiany towarów między Niemcami i Szwecją. Stacjonującej na wyspach rosyjskiej jednostce liczącej ok. 14 tys. żołnierzy nie udało się obronić wysp. Archipelag zdobyto w ciągu dziewięciu dni, a nowa linia frontu przebiegała wzdłuż zachodniego

${ }^{31}$ Vide H. Saarniit, Veel kord Eesti bolševike agraarpoliitikast Oktoobrirevolutsiooni päevil, [w:] Revolutsioonist revolutsioonini 1905-1940, red. H. Arumäe [et al.], Tallinn 1975, s. 82, 90, 91; J. Anvelt, Oktoobrirevolutsioon ja maaküsimus Eestis, „Klassivõitlus” 1919, nr 11, s. 22-25.

32 „Tööline” 18 I 1918 (31); „Päevaleht”, 23 I (5 II) 1918.

${ }^{33}$ K. Siilivask, Veebruarist oktoobrini 1917, s. 432; „Eesti Teataja”, 19 I 1918. 
wybrzeża Estonii. Można było zakładać, że wojska niemieckie w następnej kolejności podbiją jej lądową część. Rząd Tymczasowy musiał wzmocnić jednostki rozlokowane w Estonii. Liczbę rosyjskich wojsk w Estonii w październiku 1917 r. szacowano na 200 tys. żołnierzy.

Zdobycie Archipelagu Moonsundzkiego mocno skomplikowało sytuację wewnętrzną w guberni estońskiej i umożliwiło bolszewikom oskarżanie prawicowych stronnictw o współpracę z bałtyckimi baronami i o oczekiwanie na niemieckich imperialistów. Na przykład 18 stycznia Komitet Wykonawczy Estońskiej Rady Robotników i Żołnierzy opublikował wezwanie, w którym żądano, aby rady robotnicze z majątków i gmin zagwarantowały robotnikom uczestnictwo w wyborach, agitowały oraz zadbały o to, aby wyborcy włożyli do koperty do głosowania listy kandydatów tych partii, które popierają władzę bolszewicką, nie chcą odłączenia się od Rosji i są gotowe do walki przeciwko tym, którzy bezpośrednio lub z ukrycia chcą współpracować z niemieckimi imperialistami. Bolszewicy twierdzili, że jako jedyni są w stanie zapewnić narodowi lepszą przyszłość i że oprócz nich nie ma innej partii, która byłaby w stanie powstrzymać kontrrewolucję ${ }^{34}$. Opinie lewicowych eserów były pod tym względem zbieżne z opiniami bolszewików. Kręgi prawicowe oskarżały bolszewików o wrogie działania i jednocześnie rozważały losy guberni estońskiej: „Wcale nie chcemy utonąć wraz z Rosjanami w ich zamęcie. Z drugiej strony Estonii zagraża żelazna pruska pięść. Jaka ogromna strata czeka nas, jeżeli nasz los zostanie związany z Niemcami”. Uważano, że Zgromadzenie Założycielskie już na pierwszym posiedzeniu powinno rozwiązać kwestię niepodległości Estonii ${ }^{35}$. W toku kampanii wyborczej prawicowcy i centryści głosili, że wybierane Zgromadzenie Założycielskie powinno ogłosić gubernię estońską neutralnym wolnym państwem. Mówiono też o zorganizowaniu referendum w sprawie niepodległości lub przyłączenia się do jakiegoś innego państwa ${ }^{36}$.

Gazety informowały, że frekwencja w wyborach do Zgromadzenia Założycielskiego była duża i że w Tallinnie do urn poszło około 50 tys. uprawnionych do głosowania ${ }^{37}$. Niemniej wyborów tych nie udało się przeprowadzić do końca. Bolszewicy poinformowali, że z powodu zagrożenia rewolucji wybory do Zgromadzenia zostają wstrzymane. W nocy z 27 na 28 stycznia bolszewicy ustanowili we wszystkich miastach Estonii stan wyjątkowy, głosili oni, że w Estonii zbierane są podpisy, by ściągnąć do kraju niemieckie wojska, że wśród sygnatariuszy tych wezwań są również estońscy chłopi i duchowieństwo. Przyczyną stanu wyjątkowego miało być rzekoma zdrada bałtyckich Niemców i obywateli Estonii, którzy jakoby planowali zbrojne wystąpienie przeciwko bolszewickiej władzy mające nastąpić jednocześnie z natarciem niemieckich wojsk na kraj. 29 stycznia bolszewicka gazeta „Eesti Teataja” poinformowała, że osób powyżej

34 „Tööline”, 29 i 30 XII 1917 (11, 121 1918).

35 „Päevaleht”, 23 I (5 II) 1918.

${ }^{36}$ Eesti. Seltside, sõjameeste ja asunduste häälekandja, 19 I (1 II) 1918 (Estonia. Głos społeczeństw, wojowników i osiedli).

37 „Päevaleht”, 24 I 1918. 
17. roku życia, wywodzących się z bałtyckich właścicieli majątków, nie chroni prawo, co oznaczało, że można je było aresztować i mógł to zrobić każdy ${ }^{38}$. Część uwięzionych Niemców bałtyckich wysłano na Syberię, skąd uwolniono ich w marcu 1918 r. po zawarciu traktatu pokojowego w Brześciu.

Tam, gdzie wybory jednak się odbyły, wynik końcowy był następujący: kandydaci na posłów z listy Estońskiej Rady Robotników i Żołnierzy otrzymali 37,1\% głosów; z listy Stronnictwa Pracy — 29,8\%; z listy Bloku Demokratycznego - 23,3\%; z listy lewicowych eserów - 3,5\%; z listy mienszewików - 1,7\%; z listy prawicowych eserów $-1 \%$ głosów. Na pozostałe partie oddano poniżej $1 \%$ głosów. Należy zaznaczyć, że jeżeli porównamy wybory do Estońskiego Zgromadzenia Założycielskiego z listopadowymi wyborami do Rosyjskiego Zgromadzenia Ustawodawczego, to liczba głosów oddanych na bolszewików zmniejszyła się z 40,4\% do 37,1\%39. Komentowano, że naród „przesuwa” się na prawo i to dość szybko.

W istocie zwycięzcą wyborów byli jednak bolszewicy. Ich wizja przyszłości guberni estońskiej wykrystalizowała się szczególnie po wprowadzeniu stanu wyjątkowego. Poinformowali oni wtedy, że wybory do Zgromadzenia Założycielskiego, ta ostatnia „gra parlamentarna" się zakończyła i że robotnicy powinni wejść do rzeczywistego Zgromadzenia Założycielskiego, którym jest właściwy gospodarz społeczeństwa, czyli lud pracujący. Już przed wyborami, 19 stycznia, w gazetach opublikowano plan utworzenia Komuny Pracy Estonii (Eestimaa Töökommuun) sporządzony przez Anvelta. Podstawę planu stanowiła deklaracja o prawach ,pracującego i eksploatowanego ludu” przyjęta podczas III Kongresu Rad, który odbył się dniach 10-18 stycznia w Petersburgu w Pałacu Taurydzkim. Na kongresie ogłoszono, że Rosja będzie republiką sowiecką utworzoną przez wolne narody na zasadzie wolnego związku jako sowiecka federacja republik narodowych ${ }^{40}$. W pierwszym punkcie projektu zadeklarowano, że Estońska Komuna Ludu Pracującego to autonomiczna część rosyjskiej republiki sowieckiej i że jej stosunki wzajemne z republiką sowiecką i kwestie zagraniczne będą rozwiązywane na zasadzie umowy. Deklarowano, że komuna będzie niezależna we wszystkich sprawach o charakterze lokalnym i że będzie miała prawo odłączenia się od Rosji lub przyłączenia się do jakiegoś innego państwa, jak również do ogłoszenia niepodległości. Na czele komuny miał stać kongres estońskiego ludu pracującego, składający się z delegatów okręgów, gmin i miast, którzy mieli wybierać kierownictwo komuny. W celu zalegalizowania kongresu uważano za słuszne zorganizowanie wyborów. W projekcie przewidziano także możliwość organizowania referendów ${ }^{41}$. Bolszewicy byli przeciwni utworzeniu narodowych sił zbrojnych i pytali, przeciwko komu miałyby one zostać użyte.

38 Vide „Eesti Teataja” 29 I (11 II) 1918.

39 Odnośnie do wstępnych wyników wyborów vide „Päevaleht” 24 I (6 II); 25 I (7 II) 1918; vide też A. Vallner, Eesti Töörahva Kommuni teostamise lühike ülevaade, „Klassivõitlus” 1919, nr 3/4, s. 3-4.; „Päevaleht” 25 I (7 II) 1918.

40 Декларация прав трудящегося и эксплуатируемого народа. 3 (16) января 1918 г. [w:] Декреть Советской власти. т. 1., Октября 1917-16 марта 1918, Москва,1957, s. 620.

${ }^{41}$ Eesti Töörahva Kommuuni põhiseaduse eelkavatsus, „,Tööline”, 1 II (19 I) 1918. 


\section{OGLOSZENIE NIEPODLEGLOŚCI I OKUPACJA NIEMIECKA W OKRESIE OD LUTEGO DO LISTOPADA 1918 R.}

Dnia 13 lutego 1918 r. w Hamburgu odbyła się narada, w której uczestniczyli najwyżsi rangą dowódcy niemieccy oraz cesarz Wilhelm II, ponieważ Trocki jako przedstawiciel sowieckiej Rosji nie zgodził się na podpisanie traktatu pokojowego w trakcie rokowań pokojowych w Brześciu. Postanowiono, że w prowincjach bałtyckich (w Liwonii i Estonii) należy zaprowadzić ,akcję policyjną" ${ }^{42} .19$ lutego 1918 r., dzień po rozpoczęciu natarcia wojsk niemieckich, Konwent Seniorów Sejmiku Krajowego rozwiązanego przez bolszewików oraz członkowie Rządu Krajowego zebrali się na tajnej naradzie, podczas której zdecydowano wykorzystać interregnum powstałe po natarciu wojsk niemieckich w celu ogłoszenia niepodległości Estonii. Podczas narady utworzono trzyosobowy dyrektoriat, czyli Komitet Ocalenia Estonii. Należeli do niego następujący działacze ruchu narodowościowego: Konstantin Päts, Konstantin Konik i J. Vilms. 24 lutego w imieniu Komitetu Ocalenia i Konwentu Seniorów Sejmiku Krajowego opublikowano manifest do wszystkich narodów Estonii. Dodatkowo Komitet Ocalenia ogłosił utworzenie Rządu Tymczasowego Estonii.

Początkowo chodziło tylko o deklarację, akt symboliczny. Rząd Tymczasowy nie był w stanie zarządzać państwem, ponieważ 25 lutego wojska niemieckie zajęły Tallinn, a następnie całą Estonię. Niemieckie dowództwo wojskowe okupujące kraj powiadomiło, że oficerowie i żołnierze należący do jednostki narodowej, czyli Pierwszego Estońskiego Pułku, nie zostaną rozbrojeni i że pułk pozostanie pod rozkazami niemieckiego dowództwa wojskowego w celu zapewnienia porządku. Obietnicy jednak nie dotrzymano i 20 marca Niemcy ogłosiły, że jednostki narodowe zostaną rozwiązane ${ }^{43}$. Od tego momentu władzę w Estonii sprawowały niemieckie instytucje wojskowe, które ciągle wydawały postanowienia i rozporządzenia. Najbardziej znane było rozporządzenie naczelnego dowódcy niemieckich wojsk okupacyjnych i dowódcy administracji wojskowej w Estonii generała porucznika Adolfa von Seckendorffa z lutego 1918 r., na mocy którego wprowadzono w Tallinnie reżim okupacyjny. Rozporządzenie składało się z trzech części: „Ja rozkazuję”, „Ja zakazuję”, „Opór”. W ostatniej części informowano, że za złamanie nakazów i zakazów grozi kara śmierci, więzienia lub grzywny ${ }^{44}$. Zgodnie z art. VI traktatu pokojowego zawartego 3 marca, należące do Rosji ziemie Estonii i Liwonii przechodziły pod władze policyjne Niemiec. Wprawdzie z wieloznacznie interpretowanymi zastrzeżeniami: „,dopóty, dopóki działające w kraju lokalne instytucje nie będą w stanie zapewnić społecznego bezpieczeństwa"45

42 Vide Ch. Rust, Self-Determination at the Beginning of 1918 and the German Reaction, „Lithuanian Historical Studies" 2008, nr 13, s. 53.

${ }^{43}$ Kodusõda ja välisriikide interventsioon Eestis 1918-1920, [w:] Dokumente ja materjale, t. 1, red. K. Siilivask, E. Arumäe, Tallinn 1984, s. 20, 37-38.

44 Vide K.-H. Janssen, Die Baltische okupationspolitik des Deutschen Reiches, [w:] Von den Baltischen Provinzen zu den Baltischen staaten. Beiträge zur Entstehungsgeschichte der Republiken Estland und Lettland 1917-1918, oprac. J. von Hehn, Marburg 1971, s. 217-254.

45 Мирный договор между Советской Россей с одной стороны и Германией, Австро-Венгрией, с другой стороны «Брестский мир» 3 марта 1918 г; vide <http://www.hrono.ru/dokum>, dostęp 1 VI 2018. 
Taka sytuacja bardzo odpowiadała bałtyckim Niemcom. Należy jeszcze raz przypomnieć oświadczenie Komitetu Rycerstwa Estonii z 30 listopada w sprawie odłączenia guberni estońskiej od Rosji i podobną decyzję Landtagu Rycerstwa Liwonii z 17 września ${ }^{46} .12$ kwietnia 1918 r. odbyło się w Rydze zebranie Landesratu, w którym uczestniczyli posłowie wybrani na zebraniu krajowym z Liwonii, Estonii i Saaremaa oraz przedstawiciele Rygi - w przeważającej części bałtyccy Niemcy. Na tym spotkaniu podjęto decyzję o przyłączeniu się do Niemiec. Następnie przewodniczący Landesratu, marszałek krajowy rycerstwa Liwonii, były członek rosyjskiego parlamentu, baron Adolf Konstantin Pilar von Pilchau wysłał telegram do cesarza Niemiec, w którym dziękował cesarzowi za wyzwolenie mieszkańców Estonii, Liwonii, Saaremaa i Rygi. Następnie Pilar von Pilchau wystosował w imieniu uczestników zebrania prośbę do cesarza o przyłączenie na wieki krajów nadbałtyckich do państwa niemieckiego ${ }^{47}$.

Projekty dotyczące reorganizacji Rosji były gotowe w Rzeszy Niemieckiej już po rozpoczęciu wojny światowej, przy czym nazywano je także projektami dekompozycji lub polityką dekompozycji. Chodziło o oddzielenie prowincji położonych wzdłuż zachodnich granic Imperium Rosyjskiego i stworzenie z nich w pewnym stopniu niezależnych państw buforowych. Pas państw buforowych miał składać się z: Finlandii, krajów nadbałtyckich, Polski, Ukrainy i Kaukazu — terytoriów zamieszkałych przez nie-Ro$\operatorname{sjan}^{48}$. Warto wspomnieć o memorandum Heinricha Classa, przewodniczącego utworzonego w 1891 r. Związku Wszechniemieckiego, i Leopolda von Vietinghoff-Scheeli, napisanym już w grudniu 1914 r. i wysłanym do najważniejszych urzędników cywilnych i wojskowych Rzeszy, w tym do kanclerza Theobalda Bethmann-Hollwega. W memorandum wyrażono opinię, że Rosję należy odeprzeć dalej na wschód i zmienić w księstwo z epoki sprzed czasów Piotra I. Polskę i prowincje bałtyckie należące do Rosji należało - według autorów memorandum — przyłączyć do Niemiec. Granica z Rosją miała przebiegać następująco: Narwa — jezioro Pejpus — Psków — rzeka Wielikaja — Wilno — rzeka Niemen - Grodno - Działdowo (Soldau) - Włocławek - Częstochowa. Na terenach wydzielonych z Rosji Niemcy powinni byli dokonać „ucywilizowania ludności", następnie zastąpić Niemcami Rosjan mieszkających między Wołgą i Morzem Czarnym, Żydów skierować do Palestyny, a Polaków przepchnąc gdzieś na wschód ${ }^{49}$.

Po nadejściu niemieckich jednostek rozpoczęto przygotowania do utworzenia stanowego i niedemokratycznego księstwa bałtyckiego (Vereinigtes Baltisches Herzogtum). W tym celu prowadzono rozmowy zarówno z przywódcami w Berlinie, jak i z lokalnymi prawicowymi politykami. 5 listopada 1918 r. utworzono Radę Regencyjną planowanego księstwa z Pilar von Pilchauem na czele. Na posiedzeniu Landesratu potrzebę utworzenia księstwa thumaczono tym, że zniesienie caratu zwolniło bałtyckich Niemców z przysięgi, a to umożliwiało odseparowanie się od Rosji ${ }^{50}$. Głową księstwa miał zostać

\footnotetext{
46 E. Dellingshausen, Im Dienste der Heimat..., s. 318.

47 Vide Kodusõda ja välisriikide interventsioon Eestis 1918-1920..., s. 42.

48 O. Apunen, Suomi keisarillisen Saksan politikassa 1914-1915, Helsinki 1968, s. 27.

${ }^{49}$ Ibidem, s. 32-33.

${ }^{50}$ Vide E. Dellingshausen, Im Dienste der Heimat..., s. 342-345.
} 
książę Meklemburgii Adolf Friedrich. Oznaczałoby to władzę 180-200 Bałtów nad około trzema milionami Estończyków i Łotyszy. 9 listopada w Niemczech wybuchła jednak rewolucja, która obaliła władzę cesarską. Tym samym nie powiodła się również próba stworzenia księstwa. 11 listopada $\mathrm{w}$ rozejmie podpisanym w Compiègne określono także zobowiązania Niemiec wobec Europy Wschodniej. Wojska niemieckie z Europy Wschodniej musiały ponownie znaleźć się w granicach Niemiec, ale dopiero po tym, jak sojusznicy uznają, że nadszedł na to czas. Art. 15 umowy stanowił o tym, że Niemcy powinny wycofać się z traktatów w Bukareszcie i Brześciu Litewskim i z aneksów do nich.

\section{PONOWNA PRÓBA PRZEPROWADZENIA WYBORÓW DO ZGROMADZENIA ZALOŻYCIELSKIEGO}

Dnia 11 listopada 1918 r. Tymczasowy Rząd Estonii oświadczył, że ponownie rozpoczyna działalność. Następnego dnia po rokowaniach z Iwanem Poską, byłym komisarzem guberni estońskiej i ministrem spraw zagranicznych ogłoszonego w 1918 r. Rządu Tymczasowego, dowódca niemieckich wojsk okupacyjnych Seckendorff oznajmił, że uznaje Rząd Tymczasowy Estonii i to bez stosownej decyzji rządu Niemiec. Tego samego dnia Rząd Tymczasowy poinformował mieszkańców Estonii, że głównym zadaniem rozpoczynającego swą działalność Sejmiku Krajowego jest zwołanie estońskiego Zgromadzenia Założycielskiego wybranego w powszechnych, bezpośrednich i tajnych wyborach na podstawie proporcjonalnej ordynacji wyborczej ${ }^{51}$.

Dnia 13 listopada Ogólnorosyjski Centralny Komitet Wykonawczy anulował układ pokojowy z Brześcia i uzupełniające go umowy ${ }^{52}$. Założony potem bolszewicki Tymczasowy Komitet Rewolucyjny Estonii 21 listopada poinformował, że okupacja niemiecka w Estonii dobiegła końca i że on przejmuje władzę ${ }^{53} .28$ listopada w ręce bolszewików przeszła Narwa, w której dzień później proklamowano powstanie bolszewickiego państwa - Estońskiej Socjalistycznej Republiki Radzieckiej, czyli Estońskiej Komuny Ludu Pracującego (Eesti Töörahva Kommuun). Jej przewodniczącym został Jaan Anvelt, członek Tymczasowej Rady Ziemskiej Guberni Estońskiej ${ }^{54} .7$ grudnia 1918 r. Rada Komisarzy Ludowych Rosji uznała niezależność Estońskiej Republiki Radzieckiej. Podobne komuny ludu pracującego proklamowano również w Rydze i Wilnie.

Następnie 24 grudnia wydano decyzję Ogólnorosyjskiego Centralnego Komitetu Wykonawczego w sprawie niezależności radzieckich republik: Estonii, Łotwy i Litwy ${ }^{55}$. Estońska Komuna Ludu Pracującego wspierana przez wojsko Rosji sowieckiej anulowała długi chłopów wobec właścicieli majątków, umorzyła roszczenia z tytułu najmu itd., ale nie rozdała jednak ludowi ziemi pochodzącej z majątków. Zamiast tego rozpoczęto tworzenie - często odgórnie i na siłę - państwowych gospodarstw.

51 Vide „Päevaleht”, 12 XI 1918.

52 Документы внешней политики СССР. 7 ноября 1917-31 декабря 1918, т. 1, Москва 1959, s. 565.

53 Kodusõda ja välisriikide interventsioon Eestis 1918-1920..., s. 115.

${ }^{54}$ Ibidem, s. 118-121. Wyrzucenie Anvelta z Rady Ziemskiej zostało sformalizowane dopiero 5 lutego $1919 \mathrm{r}$.

${ }^{55}$ Kodusõda ja välisriikide interventsioon Eestis 1918-1920..., s. 126, 161. 
W Estonii powstały więc tym samym dwa wrogie sobie ośrodki władzy: obywatelski, wspierany początkowo przez wojsko niemieckie, z siedzibą w Tallinnie i bolszewicki, wspierany przez sowiecką Rosję, z siedzibą w Narwie. W zaistniałej sytuacji Rządowi Tymczasowemu Estonii udało się jednak otrzymać pomoc z Anglii i Finlandii, zorganizować efektywny opór przeciwko bolszewikom oraz utrzymać się przy władzy. Ostatnie niemieckie jednostki wojskowe opuściły Estonię 25 grudnia.

Dnia 23 listopada 1918 r. Rada Ziemska podjęła decyzję o wyborach do Zgromadzenia Założycielskiego. W tym celu ogłoszono ustawę o wyborach, która została przetłumaczona również na język rosyjski ${ }^{56}$. Zgodnie $\mathrm{z}$ tą ustawą, w celu przeprowadzenia wyborów stworzono Główny Komitet Wyborczy do Zgromadzenia Założycielskiego, któremu podporządkowano komisje miejskie, okręgowe i rejonowe. Kierownikiem Głównego Komitetu Wyborczego został przewodniczący Sejmiku Krajowego, któremu podlegało sześciu wybranych członków. Zgodnie z przepisami ustawy, Zgromadzenie Założycielskie miało liczyć 100 członków wybranych przez obywateli w powszechnym, tajnym i bezpośrednim głosowaniu na podstawie proporcjonalnej ordynacji wyborczej. W wyborach do Zgromadzenia Założycielskiego mogły brać udział osoby obu płci, które w dniu wyborów miały ukończone 20 lat. Za obywateli Estonii według postanowienia Sejmiku Krajowego z dnia 26 listopada 1918 r. uważano wszystkie osoby, które zamieszkały w Estonii i które na dzień 24 lutego 1918 r. były poddanymi Rosji, niezależnie od ich narodowości i wyznania, w tym także osoby, których nazwiska widniały na listach instytucji państwowych Rosji działających na terenie Estonii. Ustawa wyborcza zawierała także wiele wyłączeń: prawa wyborczego nie posiadały osoby chore psychicznie, osoby objęte śledztwem i osoby skazane przez sąd w postępowaniu karnym. W niektórych przypadkach ostatnie zastrzeżenie obejmowało też osoby, które odbyły już swoją karę, np. osoby skazane na prace przymusowe nie mogły wziąć udziału w wyborach, jeżeli od momentu zakończenia odbywania kary nie minęło 10 lat ${ }^{57}$. Dla wojska stworzono Centralną Wojskową Komisję Wyborczą, której podporządkowano wojskowe komisje wyborcze $\mathrm{w}$ formacjach, którym z kolei podlegały komisje wyborcze działające w sztabach jednostek. Walczących na frontach oraz członków Ligi Obrony (organizacji paramilitarnej, Kaitseliit), posiadających prawo wyborcze wpisano na wojskowe listy wyborców. W odróżnieniu od wyborów do Zgromadzenia Założycielskiego, które odbyły się na początku 1918 r., w pracach Głównego Komitetu Wyborczego do Zgromadzenia Założycielskiego uczestniczyli także członkowie Deutsch Partei in Estland. Członkiem Centralnej Wojskowej Komisji Wyborczej do Zgromadzenia Założycielskiego był również Axel de Vries, który dołączył do Batalionu Bałtyckiego składającego się z bałtyckich Niemców ${ }^{58}$.

${ }^{56}$ Maapäeva istungi protokoll, 23 XI 1918 (protokół posiedzenia Maapäev). ERA 78-1115, s. 14.

${ }^{57}$ Eesti Asutava Kogu Valimisseadus (ustawa o wyborach do Estońskiego Zgromadzenia Założycielskiego); Eesti Asutava Kogu Walimiste Peakomitee Valga linnavalitsusele, 3 III 1919 (Główny Komitet Wyborczy do Estońskiego Zgromadzenia Założycielskiego do Urzędu Miasta Valga). ERA 15-1-30, s. 46.

58 Asutava Kogu valimiste Peakomitee Asutava Kogu valimiste sõjaväe keskkomisjonile, 15 III 1918 (Główny Komitet Wyborczy do Zgromadzenia Założycielskiego do wojskowej komisji wyborczej). ERA 15-1-30, s. 18. 
Dnia 25 listopada Sejmik Krajowy podjął decyzję o zorganizowaniu w dniach 1, 2 i 3 lutego 1919 r. ${ }^{59}$ wyborów do Zgromadzenia Założycielskiego. Wiadomość o tym opublikowano 3 grudnia. Zgodnie z okólnikiem Głównej Komisji Wyborczej do Zgromadzenia Założycielskiego opublikowanym 7 grudnia, listy wyborcze powinny zostać opublikowane 1 stycznia 1918 r. ${ }^{60}$ Biorąc pod uwagę działania wojskowe skierowane przeciwko nacierającym od wschodu bolszewikom, decyzją Rady Ziemskiej z 27 grudnia 1918 r. wybory przełożono na czas nieokreślony ${ }^{71}$. Na posiedzeniu Tymczasowej Rady Ziemskiej i Głównego Komitetu Wyborczego do Zgromadzenia Założycielskiego, które odbyło się 8 lutego 1919 r., ustalono nowy termin wyborów: 5, 6, 7 kwietnia 1919 r. Termin pierwszego posiedzenia Zgromadzenia Założycielskiego ustalono natomiast na 23 kwietnia. Przewodniczącym Głównego Komitetu Wyborczego został Ado Birk.

Na podstawie $\S 10$ ustawy wyborczej listy kandydatów przedstawiły następujące stronnictwa i ruchy: Partia Mieszkańców Wysp Hiiu (3 kandydatów), Estońska Socjaldemokratyczna Partia Robotników (99 kandydatów), Estońskie Stronnictwo Pracy (120 kandydatów), Deutsch Partei in Estland (31 kandydatów), Estoński Związek Mieszkańców Wsi (98 kandydatów), Chrześcijańskie Stronnictwo Narodowe (64 kandydatów), Estońskie Stronnictwo Narodowe (120 kandydatów), Estońska Partia Socjalistów-Rewolucjonistów (64 kandydatów), Sojusz Obywateli Rosyjskich (9 kandydatów), Ogólnoestoński Związek Marynarzy (7 kandydatów) ${ }^{61}$. Łącznie w wyborach do Zgromadzenia Założycielskiego startowało 615 kandydatów na posłów. Ustawę o wyborach przetłumaczono także na język rosyjski.

Wybory do Zgromadzenia Założycielskiego odbyły się w lutym i marcu 1919 r., kiedy kraj znajdował się w stanie wojny, w czasie, kiedy jednostki estońskie walczyły z bolszewikami. Było to jedną z przyczyn prowadzenia bardzo agresywnej kampanii wyborczej przez konkurencyjne stronnictwa. Krytykowały one zarówno siebie nawzajem, jak i działania rządu. Stronnictwo Narodowe skupiło się na kwestii gruntów i propagowało tworzenie małych gospodarstw rolnych, tzn. zagród, których powierzchnia wynosiłaby 40-50 dziesięcin. Robotnikom w miastach obiecano ośmiogodzinny dzień pracy, w marynarce i w rolnictwie dzień pracy mógł być dłuższy.

W wyborach uczestniczyło 458 tys. osób. Dla porównania w wyborach do Rosyjskiego Zgromadzenia Ustawodawczego z listopada 1917 r. w Estonii uczestniczyło

59 Asutava Kogu valimiste peakomitee Teadanne nr 1., 3 XII 1918 (ogłoszenie nr 1 Głównego Komitetu Wyborczego do Estońskiego Zgromadzenia). ERA 15-1-1, s. 58.

${ }^{60}$ Eesti Asutava Kogu Walimiste Peakomitee ringkiri, 7 XII 1918 (okólnik Głównego Komitetu Wyborczego do Estońskiego Zgromadzenia Założycielskiego). ERA 15-1-30, s. 155. Eesti Asutava Kogu Walimiste Peakomitee teadaanne nr 3, 29 XII 1918 (ogłoszenie nr 3 Głównego Komitetu Wyborczego do Estońskiego Zgromadzenia). ERA 15-1-30, s. 129. Eesti Asutava Kogu Walimiste Peakomitee Teadanne nr 5, 10 II 1919 (ogłoszenie nr 5 Głównego Komitetu Wyborczego do Estońskiego Zgromadzenia). ERA 15-1-1, s. 57.

${ }^{61}$ Eesti Asutava Kogu Walimiste Peakomitee Teadanne nr 5, 10 II 1919 (ogłoszenie nr 5 Głównego Komitetu Wyborczego do Estońskiego Zgromadzenia). ERA 15-1-1, s. 57. Eesti Asutava Kogu Walimiste Peakomitee ringkiri, 14 III 1919 (okólnik Głównego Komitetu Wyborczego do Estońskiego Zgromadzenia Założycielskiego). ERA 15-1-30, s. 24. 
312 tys. wyborców, a w wyborach do Zgromadzenia Założycielskiego, które odbywały się na początku 1918 r., zdążyło zagłosować 235 tys. osób. Wybory do Zgromadzenia Założycielskiego zakończyły się zwycięstwem socjalistów. Estońska Socjaldemokratyczna Partia Robotników otrzymała 41 mandatów, Estońskie Stronnictwo Pracy - 30, Estońskie Stronnictwo Narodowe - 25 mandatów, Estońska Partia Socjalistów-Rewolucjonistów - 7, Estoński Związek Mieszkańców Wsi - 8, Estońskie Chrześcijańskie Stronnictwo Narodowe - 5, Deutsch Partei in Estland - 3 mandaty, a Sojusz Rosyjskich Obywateli — jeden mandat. Trzy stronnictwa wymienione jako pierwsze stworzyły w Zgromadzeniu Założycielskim koalicję centrolewicową. W Zgromadzeniu Założycielskim znalazło się 25 prawników, 11 dziennikarzy, 7 agronomów, 3 nauczycieli, 2 pisarzy. W jego skład weszły także 4 kobiety.

\section{DZIALALNOŚĆ ZGROMADZENIA ZALOŻYCIELSKIEGO (ASUTAV KOGU)}

Dnia 23 kwietnia 1919 r. w sali Teatru Estonia rozpoczęły się pierwsze uroczyste obrady Zgromadzenia Założycielskiego reprezentującego naród estoński. Przybyli również przedstawiciele kilku obcych państw oraz zagraniczni dziennikarze. Przewodniczącym Zgromadzenia Założycielskiego został socjaldemokrata August Rei. W przemówieniu inaugurującym Zgromadzenie Założycielskie Rei nazwał kwestię ziemi zagadnieniem życiowo ważnym dla estońskiego narodu i państwa. Już 17 lutego, przed zwołaniem Zgromadzenia Założycielskiego, Rząd Tymczasowy Estonii zdecydował o wywłaszczeniu majątków rycerskich i przekazaniu ich do dyspozycji ministerstwa rolnictwa ${ }^{62}$. Tego samego dnia utworzono 20-osobową komisję, która miała sporządzić projekt ustawy o ziemi. Następnego dnia wybrano członków komisji konstytucyjnej i jej przewodniczącego - J. Tõnissona, po czym komisja rozpoczęła prace nad projektem konstytucji Estonii opracowanym przez kierownictwo Estońskiej Rady Ziemskiej.

Zgromadzenie Założycielskie powoływało także rządy. Pierwszym z nich był rząd Otto Strandmana, zatwierdzony 8 maja. W czasie kadencji Zgromadzenia Założycielskiego w Estonii zmieniło się pięć ekip rządzących. Zgromadzenie Założycielskie istniejące od 23 kwietnia 1919 r. do 20 grudnia 1920 r. odbyło łącznie pięć sesji, 170 posiedzeń i przyjęło 800 ustaw.

Dnia 19 maja Zgromadzenie Założycielskie zatwierdziło swój pierwszy istotny dokument „Interpretacja Estońskiego Zgromadzenia Założycielskiego w kwestii niepodległości i niezależności państwa estońskiego"633 w którym zawarto przegląd historii Estonii i podsumowano akty normatywne stanowiące o państwowości Estonii. Deklarowano, że związki, które łączyły Estonię z Rosją, ostatecznie zostały rozerwane i że naród Estonii musi walczyć ze wszystkich sił z bolszewicką i agresywną Rosją. W ten sposób chciano pokazać zarówno społeczeństwu estońskiemu, jak i przede wszystkim

${ }^{62}$ „Riigi Teataja” 1919, nr 1.

${ }^{63}$ Eesti Asutava Kogu seletus Eesti riiklikust iseseisvusest ja rippumatusest, <https://www.riigi kogu.ee>, dostęp 1 VI 2018. 
innym państwom, że w kwestii niepodległości w Zgromadzeniu Założycielskim panuje zgoda. Było to istotne również w kontekście uznania Estonii przez pozostałe państwa. W czasie głosowania z sali wyszli posłowie należący do Deutschbaltische Partei in Estland. Przedstawiciel Sojuszu Obywateli Rosji wstrzymał się od głosu.

Dnia 10 października 1919 r. Zgromadzenie Założycielskie przyjęło ustawę o ziemi, przy 63 głosach za, 9 - przeciw i jednym pośle wstrzymującym się od głosu. 20 posłów odmówiło wzięcia udziału w głosowaniu, a 27 nie pojawiło się na sali. W Zgromadzeniu Założycielskim byli również tacy, szczególnie wśród Związku Mieszkańców Wsi, ale też wśród członków Stronnictwa Narodowego, którzy uważali, że rozdzielanie gruntów należących wcześniej do majątków ziemskich między właścicieli niewielkich gospodarstw rolnych jest bezsensowne, ale i tacy, którzy uważali, że wywłaszczenia gruntów nie można dokonywać bez rekompensaty. Ustawę o ziemi później jeszcze uzupełniano i poprawiano. Uchwalenie tej ustawy i wydawanie postanowień dotyczących wprowadzenia jej w życie miało usatysfakcjonować wszystkich zainteresowanych ziemią i jednocześnie zachęcić żołnierzy do walki na froncie.

Zgodnie z punktem I.1.1. ustawy o ziemi wszystkie majątki i nadania ziemskie znajdujące się w granicach Republiki Estońskiej, których posiadanie zapewniała ich właścicielom bałtycka ustawa specjalna z 1865 r., wywłaszczono na korzyść państwa w celu stworzenia państwowych zasobów ziemi. W ustawie określono obowiązki i wysokość zapłaty za wywłaszczone grunty. Postanowiono też, że wskazanie gruntów wywłaszczanych bez zapłaty może odbywać się na podstawie stosownej ustawy specjalnej. Lasy należące do wywłaszczanych majątków nie podlegały podziałowi, tylko pozostawały własnością państwa. W celu dokonywania operacji płatniczych związanych z wdrożeniem w życie ustawy o ziemi należało założyć Bank Ziemski (Maapank). Ziemię w pierwszej kolejności otrzymywali: żołnierze, którzy odznaczyli się wybitną odwagą podczas wojny o niepodległość (wojna estońsko-bolszewicka, Vabadussõda), żołnierze, którzy w wojnie o niepodległość doznali uszczerbku na zdrowiu, rodziny żołnierzy, którzy polegli w wojnie o niepodległość, żołnierze uczestniczący w wojnie o niepodległość. W tym ostatnim przypadku brano pod uwagę czas trwania służby. W trakcie reformy rolnej tworzono prężne gospodarstwa rodzinne, posiadające zgodnie z normą dwa konie, a także mniejsze gospodarstwa (3-5 ha) i siedliska. Na mocy ustawy o ziemi państwo wywłaszczyło łącznie 1065 wielkich gospodarstw, 2246494 ha, w tym z majątków rycerskich 1934678 ha, czyli 96,6\% wielkich posiadłości ziemskich. Do końca 1923 r. założono 19828 zagród siedliskowych o łącznej powierzchni 421345,5 ha. Żołnierzom, którzy walczyli o niepodległość, przypadło 9242 zagród (46,6\% ogólnej liczby zagród siedliskowych). Około 100 majątków nie rozparcelowano i pozostawiono jako majątki państwowe, które w 1922 r. podporządkowano Zarządowi Majątków Państwowych Ministerstwa Rolnictwa. Właściciele majątków wywodzących się z bałtyckich Niemców, którzy nie uczestniczyli w działaniach wojennych przeciwko niepodległości Estonii, zachowali część swoich posiadłości o średniej wielkości ok. 80 ha. Na mocy ustawy o ziemi i ustaw ją uzupełniających na korzyść państwa wywłaszczono 1703 nierucho- 
mości, w tym: 619 majątków osób prywatnych, 874 majątki rycerskie i 256 gruntów wiejskich, 260 gruntów kościelnych i klasztornych, a także 313 gruntów z terenów stanowiących zaplecze Pieczory i Narwy. Wraz z wywłaszczeniem gruntów wielkich majątków ziemskich państwo otrzymało również znajdujące się na nich przedsiębiorstwa przemysłowe: gorzelnie (225), młyny (344), zakłady obróbki kamienia i gliny (63), tartaki (74), mleczarnie (18), a także 10808 koni i 30219 krów dla nowych nabywców ziemi. Ustawodawstwo pozwalało na zaciąganie nisko oprocentowanych długoterminowych kredytów, np. na zakup drewna na budowę (1920), na zakup inwentarza (1921), na budowę budynków mieszkalnych i chlewów (1922), na uzdatnienie ziemi (1923), na budowę (1925). Reforma rolna nie zaspokoiła roszczeń wszystkich osób, które chciały posiadać ziemię.

Ekspropriacja gruntów i mienia była bardzo radykalnym krokiem. Część bałtyckich Niemców pozbawionych ziemi opuściła Estonię. Tak zwani nowi Niemcy, którzy przeprowadzili się za granicę, zaczęli żądać rekompensaty za wywłaszczoną ziemię. Doprowadziło to do napięć w stosunkach między Estonią a Republiką Weimarską, a następnie hitlerowskimi Niemcami, które trwały aż do połowy lat trzydziestych XX w. Niemieckie kręgi rządzące ciągle naciskały na Estonię w kwestii rekompensat za wywłaszczone grunty. Sytuację komplikowało jeszcze bardziej to, że wśród osób żądających zadośćuczynienia byli obywatele Włoch, Francji, Anglii i Finlandii. W marcu 1926 r. uchwałą parlamentu estońskiego (Riigikogu) przyznano rekompensaty za ziemie odebrane osobom, które nie zwalczały zbrojnie niepodległości Estonii ${ }^{64}$. Jednocześnie na przykład łotewski Sejm (Saeima) zdecydował w 1924 r., że za ziemie wywłaszczone w toku reformy rolnej nie będą wypłacane rekompensaty. Dla pewnej części nowych Niemców początkową kwotę zadośćuczynienia w wysokości 12800 tys. koron uważali za niewystarczającą, w związku z czym żądali jej podwyższenia i grozili założeniem sprawy w sądzie międzynarodowym. W końcu 1931 r. osiągnięto porozumienie. Estonia zwiększyła kwotę wypłacaną od 1926 r. o kolejne $7 \mathrm{mln}$ koron. Dodatkową rekompensatę zaczęto wypłacać w ratach, do czego wykorzystywano różnorodne transakcje. Relacje między Estonią a Niemcami były bardzo napięte jeszcze w latach 1933-1934, ponieważ wypłata rekompensat wciąż się przeciągała z powodu kryzysu gospodarczego ${ }^{65}$. W $1934 \mathrm{r}$. do wypłacenia pozostało jeszcze 1800 tys. koron rozłożonych na siedem lat. Latem tego samego roku rozpoczęły się rządowe negocjacje w sprawie szybszego wypłacania zadośćuczynień. W listopadzie tego samego roku powiadomiono Niemcy, że rząd estoński postanowił wypłacić całą kwotę w jednej transzy ${ }^{66}$.

W czerwcu 1919 r. uchwalono tryb sprawowania rządów w Republice Estońskiej, a następnie zaczęto pisać jej konstytucję. Twórcy, którzy nad nią pracowali, inspiro-

${ }^{64}$ Vide „Riigi Teataja”, 23 III 1926. Riigikogu väliskomisjoni koosoleku protokoll, 2 XII 1931 (protokół zebrania komisji ds. Zagranicznych Riigikogu). RA BA.

${ }^{65}$ Seljamaa vestlus Reinebeckiga, 27 X 1933 (rozmowa Seljamaa z Reinbeckiem). ERA 957-13-643, s. 211-212. ERA 957-12-380, s. 41.

${ }^{66}$ Memorandum, 10 XI 1934. ERA 957-8-1324, s. 76, 88; 94-95; Memorandum by Seljamaa, 15 I 1935. ERA 95719-764, s. 61-64. 
wali się konstytucjami Republiki Weimarskiej, Francji i Konfederacji Szwajcarskiej z 1874 r. Ta ostatnia była szczególnie demokratyczna, położono w niej nacisk na ochronę podstawowych praw obywateli. 15 czerwca 1920 r. Zgromadzenie Założycielskie uchwaliło pierwszą estońską konstytucję, która weszła w życie 21 grudnia $1920 \mathrm{r}$. Natomiast nie zorganizowano referendum w sprawie jej przyjęcia. Konstytucja ta była $\mathrm{w}$ istocie aktem deklaratywnym, a nie normatywnym, określono w niej jedynie zasady, ale nie dopracowano dokładnie przepisów. Zgodnie z konstytucją Estonia była republiką demokratyczną, w której najwyższą władzę posiadał naród. Tym samym podstawę ustawy zasadniczej Estonii stanowiła zasada suwerenności. Władzę państwową podzielono na trzy filary: ustawodawczą, wykonawczą i sądowniczą, ale relacje między tymi rodzajami władzy nie zostały jednak zrównoważone. Jednoizbowy parlament — Riigikogu, składający się ze 100 posłów, który miał posiadać tylko władzę ustawodawczą, kontrolował także władzę wykonawczą i sądowniczą. Ponieważ rząd podlegał bezpośrednio parlamentowi, to sam nie dysponował szerokimi pełnomocnictwami. Brak równowagi we władzy skutkował brakiem stabilności. Rządy szybko się zmieniały i często nie były w stanie wypełniać swoich obowiązków. Podczas wyborów do pierwszego Riigikogu w listopadzie $1920 \mathrm{r}$. kandydowało 16 stronnictw, a do parlamentu dostali się przedstawiciele $10 \mathrm{z}$ nich. Wskazywało to na rozwarstwienie sił politycznych. Brak równowagi we władzy przypieczętował późniejszy los estońskiej demokracji.

W konstytucji nie przewidziano instytucji prezydenta, choć niektórzy z twórców konstytucji popierali ją. Istotną rolę $\mathrm{w}$ rezygnacji z niej odegrali socjaldemokracji. Według projektu Komisji Konstytucyjnej Zgromadzenia Założycielskiego prezydent jako głowa państwa miałby być wybierany albo przez parlament, albo przez elektorów, a nie bezpośrednio przez naród. Z niewielką przewagą Zgromadzenie Założycielskie postanowiło jednak zrezygnować z na wpół prezydenckiego ustroju państwowego i instytucja głowy państwa ze specjalnymi uprawnieniami w Estonii nie powstała. Wypełnianie obowiązków głowy państwa scedowano na prezesa rządu, starostę państwowego.

Opierając się na demokratycznej władzy centralnej i ustawodawstwie w miastach, okręgach i gminach utworzono samorządy o możliwie szerokich podstawach demokratycznych.

Zgodnie z ustawą o sądzie najwyższym Zgromadzenie Założycielskie utworzyło Sąd Państwowy (Riigikohus) w celu realizacji najwyższej władzy sądowniczej. Przy Zgromadzeniu Założycielskim działała Komisja ds. Ułaskawień, w zakres działań której wchodziło również rozpatrywanie wniosków o ułaskawienie od osób będących ofiarami represji w czasie wojny o niepodległość Estonii ${ }^{67}$. Wśród innych ustaw zasługujących na uwagę należy jeszcze wymienić: ustawę o publicznych szkołach podstawowych, ustawę o zniesieniu stanów, ustawę o sądzie najwyższym, ustawę o wspieraniu rodzin żołnierzy, ustawę o czasowym dozorze samorządów i ustawę oddzielającą

${ }^{67}$ Vide Asutava Kogu kantselei. Armuandmise Komisjoni protokollid detsember 1919-juuni 1920 (Kancelaria Zgromadzenia Założycielskiego. Protokoły Komisji ds. Ułaskawień, grudzień 1919 r.-czerwiec 1920 r.). ERA 15-2-364. 
kościół od państwa. Pozwoliło to na późniejsze przeprowadzenie reformy szkolnictwa. 13 lutego $1920 \mathrm{r}$. Zgromadzenie Założycielskie ratyfikowało układ pokojowy zawarty 2 lutego w Tartu z Radziecką Rosją.

\section{PODSUMOWANIE}

Działalność Rządu Tymczasowego, który doszedł do władzy w Rosji w lutym 1917 r., cieszyła się w ogólnych zarysach poparciem wśród estońskich narodowców. Również Komitet Estońskiego Rycerstwa potwierdził — w imieniu właścicieli majątków i lokalnych samorządów Estonii — że wspiera działalność Rządu Tymczasowego i wzywa wszystkie warstwy ludności do wypełniania jego rozporządzeń i postanowień.

Po rewolucji lutowej ruch narodowy w Estonii wnioskował o reorganizację lokalnych samorządów i przyłączenie okręgów guberni liwońskiej zamieszkałych przez Estończyków do guberni estońskiej, co zostało osiągnięte.

W październiku 1917 r., po dojściu bolszewików do władzy w Petersburgu przedstawiciele kręgów obywatelskich w Estonii zgłosili żądanie niepodległości. Główną przyczyną stawiania tych żądań był stosunek bolszewików do prawa własności. Estońscy bolszewicy uważali natomiast, że przyszłość guberni estońskiej może być związana tylko z sowiecką Rosją. Dla bałtyckich Niemców rewolucje w Rosji w 1917 r. i dążenie Estończyków i Łotyszy do autonomii oznaczały zagrożenie elitarnej pozycji Bałtów i porządku stanowego, dlatego tak ciepło witali oni okupację niemiecką i wnioskowali o przyłączenie Estonii do Niemiec lub też o utworzenie księstwa związanego z Niemcami. Projekt księstwa nie został urzeczywistniony. Okupacja niemiecka w Estonii z jednej strony przyniosła upadek władzy bolszewików, z drugiej natomiast — narodową zgodę wśród Estończyków oraz wytworzenie się poczucia wspólnoty.

Wybrane na przełomie lutego i marca 1918 r. Zgromadzenie Założycielskie wypracowało podstawy ustroju państwowego w Estonii: konstytucję i ustawę o ziemi. Uchwalenie ustawy o ziemi i rozwiązanie kwestii gruntów zgodnie z oczekiwaniami większości narodu spowodowało, że tysiące żołnierzy czuły, że walczą o swoją ziemię. To w istotny sposób przyczyniło się do zwycięstwa w wojnie o niepodległość. W wyniku wprowadzenia w życie ustawy o ziemi i innych dodatkowych decyzji w latach 1919-1939 założono 48288 gospodarstw siedliskowych. Konstytucja i ustawa o ziemi przyczyniły się do ostatecznego zlikwidowania dominacji rycerstwa nad narodem estońskim.

Tekst konstytucji uchwalonej przez Zgromadzenie Założycielskie w 1920 r. w dużej mierze znajdował także odbicie w drugiej konstytucji, zmieniła się natomiast organizacja rządów w państwie. W latach 1932 i 1933 głosowano w referendum łącznie nad trzema projektami konstytucji. Ostatni z projektów ustawy zasadniczej został poparty przez większość narodu w referendum, które odbyło się w październiku 1933 r. Ostatecznie druga konstytucja została uchwalona 24 lutego $1934 \mathrm{r}$. W tej ustawie zasadniczej przewidziano instytucję prezydenta mającego szerokie uprawnienia. Natomiast nie udało się nikogo wybrać na to stanowisko, ponieważ 12 marca 1934 r. przeprowadzono zamach stanu, który zapewnił Pätsowi, czyli naczelnikowi państwa, pozostanie u władzy. W lutym 1936 r. naczelnik państwa postanowił, że kwestia nowej konstytucji 
i wyborów do dwuizbowego parlamentu (Rahvuskogu) zostanie rozstrzygnięta w referendum. Referendum odbyło się i parlament Rahvuskogu opracował na przełomie wiosny i lata 1937 r. tekst kolejnej konstytucji, który wzorowano m.in. na polskiej ustawie zasadniczej. Konstytucja została uchwalona przez Rahvuskogu i - na mocy dekretu regenta państwowego — zaczęła obowiązywać od 1 stycznia 1938 r.

\section{BIBLIOGRAFIA}

ŹRÓDŁA

Архив новейшей истории России, t. VII, Журналы заседаний Временного правительства: март-октябрь 1917 г., т. 1. Март-апрель 1917 г.

Декреты Советской власти, т. 1, 25 октября 1917 г.-16 марта 1918 г., Москва 1957.

Документы внешней политики СССР. 7 ноября 1917-31 декабря 1918, т. 1. Москва 1959.

Мирный договор между Советской Россейб с одной стороныб и Германией, АвстроВенгрией, с другой стороны «Брестский мир» 3 марта 1918 г. Na stronie $<$ http://www. hrono.ru/dokum>.

Первая всеобщая перепись населения Российскои империи 1897 года. Эстляндская, Лифляндская губерния, ред. Н.А. Тройницкий, <https://www.twirpx.com>.

\section{PIŚMIENNICTWO}

Alston C., Antonius Piip, Zigfrīds Meierovics and Augustinas Voldemaras. The Baltic States, Haus Histories, London 2010.

Anvelt J., Oktoobrirevolutsioon ja maaküsimus Eestis, „Klassivõitlus” 1919, nr 11.

Apunen O., Suomi keisarillisen Saksan politikassa 1914-1915, Kk:n Kirjapaino, Helsinki 1968.

Barrett M.B., Operation Albion. The German Conquest of the Baltic Islands. Twentieth-Century Battles Series, Indiana University Press, Bloomington 2008.

Berendsen R., 1816 - Eestimaa talurahva vabastamise 100 - aasta juubel 23. mail 1916. Aastal, Tallinn 1916.

Brüggemann K., Baltisaksalsed ja Eesti iseseisvus 20. Sajandil, „Vikerkaar” 2018, nr 1-2.

Dellingshausen E., Im Dienste der Heimat. Erinnerungen des Freiherrn Eduard von Dellingshausen. Schriften des Deutschen Ausland-Instituts Stuttgart, Stuttgart 1930.

Eesti Asutav Kogu 70 1919-1920, 1989-1990. Dokumente ja materiale, Perioodika, Tallinn 1990.

Eesti Asutava Kogu Valimisseadus, Tallinn 1918.

Ilmjärv M., Hääletu alistumine. Eesti, Läti ja Leedu välispoliitilise orientatsiooni kujunemine ja iseseisvuse kaotus. 1920. aastate keskpaigast anneksioonini, Argo, Tallinn 2010.

Janssen K.-H., Die Baltische okupationspolitik des Deutschen Reiches, [w:] Von den Baltischen Provinzen zu den Baltischen staaten. Beiträge zur Entstehungsgeschichte der Republiken Estland und Lettland 1917-1918, Herausgegeben von Jürgen von Hehn, Marburg 1971.

Kliimann A.T., Eesti iseseisvuse areng, Tartu 1935.

Kruus H., Peetrilinnas ajaloo suurpäevil. Veebruar-märts 1917, Osaühing Noor Eesti Kirjastus, Tartu 1917.

Kurvits O., Eesti rahvusväeosad 1917-1918, [w:] Eesti rahvusväeosade album II. Toim. Oskar Kurvits. Seltsi „1 Eesti Polk” väljaanne, Tallinn 1937.

Laaman E., Eesti lahkumine Vene riigist 1917-1920, Kirjastus A/S Varrak, Tallinn 1920.

Laar M., Hiio T., Eesti riigi 100 aastat. I osa. Maapäevast Otto Tiefi valitsuseni, Post Factum, Tallinn 2018. 
Kodusõda ja välisriikide interventsioon Eestis 1918-1920. Toim: K. Siilivask, E. Arumäe, Dokumente ja materjale. Esimene köide, Tallinn 1984.

Kukk J., Kaks ,"ülewõtmist” — Iseseiswuse tuleku Päiwilt. Mälestused, Kirjastus Postimees, Tartu 1923.

Kuuli O., Sotsialistid ja kommunistid Eestis 1917-1991, Tallinn 1999.

Laaman E., Eesti iseseisvuse sünd. Toim. August Oinas, Hendrik Sepp, Juhan Vasar. K./Ü. „Loodus”, Tartu 1936.

Mägi A., Asutav Kogu Maareformi otsustamas, „Tulimuld” 1950, nr 4.

Piip A., Maanõukogu 1917. A. Vabadus tulekul I Koguteos. Eesti Maanõukogu 1917. Aasta 15./28. Nov. Otsuse tähistamiseks, Toimetanud H. Kruus, J. Ots, Tartu 1935.

Piip A., Tormine aasta. Ülevaade Eesti välispoliitika esiajast 1917.-1918. aastal dokumentides ja mälestusis, Tartu 1934.

Pullat R., Peterburi eestlased. Ajaloolis-demograafiline käsitlus XVIII sajandi algusest kuni 1917. aastani, Eesti Raamat, Tallinn 1981.

Rust C., Self-Determination at the Beginning of 1918 and the German Reaction, [w:] „Lithuanian Historical Studies" 2008.

Saarniit H., Veel kord Eesti bolševike agraarpoliitikast Oktoobrirevolutsiooni päevil, [w:] Revolutsioonist-revolutsioonini 1905-1940, red. H. Arumäe [et al.], Tallinn 1975.

Siilivask K., Veebruarist oktoobrini 1917, Tallinn 1972.

Tamm A., Eesti meeleavaldus Peterburis 26. märtsil 1917, „Kaitse Kodu” 1928, nr 3.

Vallner A., Eesti Töörahva Kommuni teostamise lühike ülevaade, „Klassivõitlus” 1919, nr 3/4. 